\title{
Instrumental Rationality
}

For the Routledge Encyclopedia of Philosophy

\author{
Jonathan Way \\ University of Southampton
}

We are instrumentally rational when we take necessary and effective means to our ends, and instrumentally irrational when we fail to do so. For instance, if you decide to give up smoking, it would be rational to stop buying cigarettes, and to limit the time you spend around other smokers. It would be irrational not to take any means to this end.

It is not clear how to formulate the principles of instrumental rationality. It is natural to think that if you have an end, you ought to take the means to that end. But if it would be wicked or crazy to take the means to one of your ends, then you ought not to take this means. In recent years, there has been considerable discussion of what to say about this issue.

It is often suggested that instrumental rationality might be all of practical rationality that to be rational in respect of one's actions is just to be instrumentally rational. This view has serious implications for the normativity of morality, since it suggests that it is not always rational to be moral. Some philosophers suggest that a proper understanding of instrumental rationality shows that we should reject this view.

\section{What is Instrumental Rationality?}

At least part of what it is to be practically rational - rational in our actions and decisions - is to be instrumentally rational - to take necessary and effective means to our ends (see 
Rationality, Practical). There are many important questions about the principles of instrumental rationality, and about the relationship between instrumental rationality and other forms of rationality. But before we can consider these questions, it will be helpful to get a clearer sense of the topic. In particular, we should ask: which of our ends are relevant to instrumental rationality? And which means are relevant?

The traditional answer to the first question is that our ends are the objects of our desires. On this view, instrumental rationality is a matter of maximising the satisfaction of our desires, or preferences. Expected utility theory is often understood as a way of developing this idea (Gauthier 1987, Dreier 1996; and see Rationality, Practical, $\S \S 1,3$, and 4). However, in recent years, many discussions of instrumental rationality have focussed on a different, although not incompatible, answer to this question. On this view, it is our intentions which are most directly relevant to instrumental rationality. This view begins by noting that it is not necessarily irrational to fail to take the means to ends you merely desire. If you want to finish working on your paper tonight, and also want to see the movie which is playing for the last time, then you will inevitably fail to take the means to one of your desired ends. But it does not follow that you are thereby irrational. There is nothing wrong with having inconsistent desires. By contrast, it does seem irrational to fail to take the means to working on your paper if that is what you intend to do. And it would be irrational for you to intend both to work on your paper and to see the movie (Harman 1976, Bratman 1987; and see Intention).

Turning now to the second question, the first thing to observe is that there are typically a wide-range of means to each of our ends. For instance, there are many ways to achieve the end of having a pleasant evening, or of getting from London to Paris. It is clear enough that instrumental rationality does not require us to take all of these means. And instrumental rationality does require us to take any necessary means and (so) some sufficient means. But beyond this, things get rather less clear. Often, it is irrational to fail to take the 
best means to one's ends. But not always. Suppose, for example, that the best way of getting from London to Paris is to fly. Still, if taking a rather more indirect route would allow you to visit some friends on route, the rational thing to do might be to take the more indirect route. In general, the choice between sufficient means to some end will turn on a range of different considerations, and not simply on which is the most efficient means to that end.

\section{Principles of Instrumental Rationality}

It is natural to think that there are principles of instrumental rationality - for example, principles requiring you to take the necessary means to your ends, and recommending that you take good non-necessary means. However, it turns out to be surprisingly difficult to formulate these principles in a plausible way. I shall focus here on the requirement to take the necessary means to one's intended ends.

We can begin with the following

(Simple Principle) If you intend to E and believe that M-ing is necessary for E-ing, you ought to $\mathrm{M}$.

While perhaps initially tempting, the simple principle is subject to a powerful objection. The problem is that the simple principle allows a kind of bootstrapping: it allows you to make it the case that you ought to $\mathrm{M}$, simply by intending to do something for which $\mathrm{M}$-ing is a necessary means. Many philosophers find this very implausible. For instance, even if you intend to pass your class and believe that cheating on the exam is a necessary means to doing so, you should not cheat on the exam, contrary to what the simple principle implies. 
Philosophers have offered a wide range of responses to this problem. I shall mention three.

Christine Korsgaard (1997) and Joseph Raz (2005), among others, propose that we replace the simple principle with something along the following lines:

(Transmission Principle) If you ought to E and M-ing is necessary for E-ing, then you ought to M.

The transmission principle does not allow for implausible bootstrapping. It says that we ought to take the means only to ends we ought to pursue, not ends we merely intend to pursue.

Since we often intend to do what we ought to do, the transmission principle explains why we are often required to take the means to our intended ends. And if we combine this principle with the common idea that what we subjectively ought to do is what, relative to our beliefs, we ought to do, then the transmission principle also explains why we are often required to take the means to ends which we believe that we ought to pursue (Schroeder 2009). Nonetheless, it is not clear that the transmission principle can explain all of the cases in which we seem to be subject to requirements of instrumental rationality. For example, we seem to be subject to demands of instrumental rationality even in the pursuit of ends which we know that we ought not to pursue (Wallace 2001). The man who decides, against his better judgment, to pursue an affair with his neighbour's wife still seems to be under a kind of rational pressure to take the means to this end. Nor does the transmission principle apply in cases in which our ends are merely permissible. For instance, I might face a choice between going to the beach and going to the mountains. Both are worth doing, but I can only do one. If I decide to go to the beach, I would be instrumentally irrational if I did not take the means 
to this end. But since it is not the case that I ought to go to the beach, the transmission principle does not explain why this is so.

Several other philosophers, including Broome (1999), Darwall (1983), and Wallace (2001), suggest that we replace the simple principle with the

(Wide-Scope Principle) You ought [to M, if you intend to E and believe that M-ing is necessary for E-ing].

The wide-scope principle is equivalent to the claim that you ought to avoid the combination of intending the end, believing that a means is necessary for this end, and failing to take this means. It therefore implies that something has gone wrong whenever you fail to take the means to an end you intend. But the wide-scope principle appears to avoid the bootstrapping objection. If you intend to E and believe that M-ing is necessary for E-ing, it does not follow from the wide-scope principle that you ought to M. You could also come to comply with the principle by dropping the intention to $\mathrm{E}$ or by dropping the means-end belief.

However, the wide-scope principle gives rise to problems of its own. First, the principle posits what may seem an objectionable symmetry between the different ways of avoiding instrumental irrationality. So far as the wide-scope principle goes, there is no difference between avoiding instrumental irrationality by taking the means to your end, dropping your end, or even dropping your means-end belief. But we might think that there is a difference here (Kolodny 2005, Schroeder 2004, 2009). Second, the wide-scope principle raises a question to which there appears to be no satisfying answer: why should you comply with this principle? What reason is there to do so? This question has been at the heart of much of the recent discussion of instrumental rationality (Kolodny 2005). Third, it has been questioned whether the principle really does avoid implausible bootstrapping. For instance, 
suppose that you are unable to give up the intention to pass the class, or the belief that cheating on the exam is necessary for doing so. In that case, the only way for you to come to comply with the wide-scope principle is by cheating on the exam. It seems to follow that you ought to cheat on the exam (Setiya 2007).

If we are not persuaded by the transmission or wide-scope principles, then we may want to reconsider whether the simple principle can be defended. One possibility here is to invoke different senses of 'ought'. The simple principle is false, it might be suggested, only when understood in the overall sense of 'ought'. In another sense of 'ought', it may still be true. Thus for example, Mark Schroeder (2009) argues that the principle is true in the subjective sense of 'ought' - the sense in which, when you falsely but reasonably believe that you have gin in your glass, you ought to take a sip. Alternatively, Stephen Finlay (2010) suggests that the principle is true in a distinctive 'instrumental' sense of 'ought'. In this sense, very roughly, to say that if you intend the end, you ought to take the means is just to say that you will not achieve the end unless you take the means. The challenge for both of these views is to establish that there really is such a sense of 'ought', that the simple principle is true in this sense, and that its truth can help to explain why failing to take the means to one's ends is a rational failing.

\section{Could Instrumental Rationality be all of Practical Rationality?}

It is often suggested that instrumental rationality might be all of practical rationality. This suggestion has important implications for the normativity of morality. For if instrumental rationality is all of practical rationality, then it is rational to be moral only if being moral is a good means to one's ends. And since we seem to be able to imagine cases in which being 
moral is not a good means to one's ends, it seems to follow that it is not always rational to be moral.

There is a vast literature on this issue (see Practical Reason and Ethics). Here I focus on the claim, sometimes made in connection with the transmission and wide-scope principles, that a correct understanding of instrumental rationality reveals that instrumental rationality could not be all of practical rationality.

The claim that instrumental rationality is all of practical rationality can be understood in at least two ways. On one understanding, it is to say that the principles of instrumental rationality are the only principles of practical rationality. We can call this view instrumentalism. On another understanding, it is to say that what one has reason to do essentially depends on what one's desires are. We can call this the desire-based view. Both of these views take inspiration from Hume's famous claim that 'reason is and ought only to be the slave of the passions' (see Hume, David 1711-76, §10). However, it is crucial to distinguish these views.

Consider the transmission principle. Since this principle says that there is a reason for the means only if there is reason for the end, it is clear that this could not be the only principle of practical rationality. So instrumentalists cannot endorse the transmission principle (Korsgaard 1997). However, the transmission principle is perfectly consistent with desire-based views, since desire-based views need not deny that there can be reasons for final ends. For instance, proponents of desire-based views may hold that wanting to do something for its own sake gives you a reason to do that very thing (Hubin 1999). Or they may claim that wanting something as an end gives you a reason to want other things as ends. For instance, wanting pleasure as an end may give you a reason to desire friendship as an end, since wanting friendship as an end is itself a means to pleasure (Harman 1976, Schroeder 2007). 
By contrast, the wide-scope principle, and its analogues for non-necessary means, could be the only principles of practical rationality. More plausibly, it could be that to be practically rational is simply to have attitudes, and take actions, which fit together in a coherent way, where the wide-scope principle is one of the principles which tell us what it is to be coherent. Many philosophers have held views along these lines (Dreier 1996, Gauthier 1987, Smith 1994). What is less clear is whether the wide-scope principle is consistent with desire-based theories. The wide-scope principle says that there is something that everyone ought to do - whatever your desires, you ought not to intend an end and not take the necessary means. So it looks as if, if this principle is true, there is at least one requirement which does not depend on our desires (Schroeder 2004).

This argument is a little quick. There are ways in which desire-based theories can allow that there are some things which everyone ought to do. For instance, the wide-scope principle might depend on some desire which is shared by every rational agent. Or perhaps the principle can be grounded in a range of desires, at least one of which is held by every rational agent. Nonetheless, it would require considerable argument to vindicate either of these claims. So the truth of the wide-scope principle would at least pose an important challenge for desire-based views. This is one way in which the debate over the correct formulation of principles of instrumental rationality has important implications for broader debates about the nature of reasons, and the normativity of morality.

\section{References and Further Reading}

Bratman, M. (1987) Intentions, Plans and Practical Reason, Cambridge, MA: Harvard University Press. (Defends the view that intentions are irreducible to beliefs and desires, and subject to distinct principles of rationality). 
Broome, J. (1999). 'Normative Requirements', Ratio 12 (4): 398-419. (Very clear and influential defence of the wide-scope principle).

Darwall, S. (1983). Impartial Reason, Ithaca: Cornell University Press. (Argues against a range of broadly Humean views of practical rationality, and defends a broadly Kantian alternative).

Dreier, J. (1996) 'Rational Preference: Decision Theory as a Theory of Practical Rationality', Theory and Decision 40 (3): 249-76. (Defends the view that the axioms of decision theory are the only principles of practical rationality).

Finlay, S. (2010). 'What Ought Probably Means, and Why You Can't Detach It', Synthese 177 (1): 67-89. (Defends the simple principle, interpreted as a claim about a distinctive instrumental sense of 'ought').

Gauthier, D. (1987) Morals by Agreement. Oxford: Clarendon Press. (Reasonably accessible presentation and defence of the view that instrumental rationality, understood as a matter of maximising the satisfaction of one's preferences, is all of practical rationality).

Harman, G. (1976) 'Practical Reasoning', reprinted in his Reasoning, Meaning and Mind. Oxford: Oxford University Press, 1999, 46-74. (Wide-ranging discussion of intentions and their role in practical reasoning).

Hubin, D.C. (1999) 'What's Special About Humeanism?' Nous 33 (1): 30-45. (Defends the transmission principle alongside a desire-based theory of reasons).

Raz, J. (2005) 'The Myth of Instrumental Rationality', Journal of Ethics and Social Philosophy 1/1. www.jesp.org. (Argues that instrumental rationality is not a distinctive form of rationality. Includes influential discussions of the transmission principle and the widescope principle).

Kolodny, N. (2005) 'Why Be Rational?', Mind 114 (455): 509-63. (Argues that there is no reason to comply with principles such as the wide-scope principle). 
Korsgaard, C. (1997) 'The Normativity of Instrumental Reason', in G. Cullity and B. Gaut (eds), Ethics and Practical Reason, Oxford: Oxford University Press, 1997, 215-54. (Argues that instrumental rationality could not be all of practical rationality. Includes important discussions of Hume and Kant's views of instrumental rationality).

Schroeder, M. (2004) 'The Scope of Instrumental Reason', Philosophical Perspectives 18 (1): 337-64. (Argues against wide-scope principles in a range of domains).

(2007) Slaves of the Passions. Oxford: Oxford University Press. (An important recent defence of a desire-based theory of reasons).

(2009) 'Means-End Coherence, Stringency, and Subjective Reasons', Philosophical Studies 143 (2): 223-248. (Defends the simple principle, interpreted as a claim about what you subjectively ought to do).

Setiya, K. (2007) ‘Cognitivism About Instrumental Reason’, Ethics 117 (4), 649-73.

(Defends the view that the principles of instrumental rationality derive from principles of theoretical rationality).

Smith, M. (1994) The Moral Problem. Oxford: Blackwell Press. (Chapter 5 defends the view that to be rational is to be coherent. Smith argues that this view can vindicate the claim that it is rational to be moral).

Wallace, R.J. (2001). 'Normativity, Commitment, and Instrumental Reason', Philosophers' Imprint 1 (3). www.philosophersimprint.org/001003. (Defends the wide-scope principle. Includes helpful discussions of Korsgaard and Broome's views of instrumental rationality). Way, J. (2010) 'Defending the Wide-Scope Approach to Instrumental Reason', Philosophical Studies, 147 (2): 213-33. (Defends the wide-scope principle against several objections). Williams, B. (1979). 'Internal and External Reasons', reprinted in his Moral Luck, Cambridge: Cambridge University Press, 1981, 100-110. (Very influential defence of a desire-based theory of reasons). 